\title{
PERCEPTION OF PACKAGING FUNCTIONS AND THE INTEREST IN INTELLIGENT AND ACTIVE PACKAGING
}

\author{
MARTINA NOSÁL'OVÁ \\ ERIKA LOUČANOVÁ \\ JÁN PAROBEK
}

\begin{abstract}
The importance of packaging functions is still growing and, consequently, the approach to packaging is more innovative and creative, resulting in the creation of packaging with innovative features in the form of active and intelligent packaging. This paper explores preferential packaging functions and preferences of customers according to intelligent and active packaging. The survey was conducted with 200 respondents, who can be defined as the millennials (people born in 1980-2000). This age group was chosen due to previous research results, which confirmed that intelligent and active packaging are most attractive for respondents of this age. Protection function is still perceived as the primary one and most importantly ensuring the freshness and shelf life of products. Respondents' interest is slightly higher in active packaging as they extend the protection of the product and thus extend shelf life of the product, but also its safety. The analysis allows for more specific suggestions for active and intelligent packaging marketing with respect to the customers' requirements.
\end{abstract}

Keywords: innovative packaging functions, active, intelligent, millennials' preferences.

JEL codes: O31, O33, D12.

Dr Martina Nosál'ová, Technical University in Zvolen, Department of Marketing, Trade and World Forestry, T.G. Masaryka 24, 96053 Zvolen, Slovak Republic (nosalova@tuzvo.sk). ORCID iD: 0000-0001-8648-2343. Dr Erika Loučanová, Technical University in Zvolen Department of Marketing, Trade and World Forestry, T.G. Masaryka 24, 96053 Zvolen, Slovak Republic (loucanova@tuzvo.sk). ORCID iD: 0000-0003-0505-3251. Dr Ján Parobek, Technical University in Zvolen Department of Marketing, Trade and World Forestry,

T.G. Masaryka 24, 96053 Zvolen, Slovak Republic (parobek@tuzvo.sk). ORCID iD: 0000-0002-3441-934X. 


\section{Introduction}

Innovation is a creative process in which two or more things are combined in a new way to produce a unique new item (Kollár, 1999). The growing importance of innovation is related, in particular, to factors such as market saturation, an effort to product profitability and ecological aspects (Jakubíková, 2005). From the perspective of packaging, several types of innovation are distinguished, based on changing packaging size, changing the form and design of packaging, or innovation based on new supplements (Kotler and Trias de Bes, 2005).

The innovative approach has led to the creation of packaging with interactive features. The continuing effort to innovate in food and beverage packaging is largely due to the needs and demands of consumers that are affected by changing global trends, such as the expected higher average durability (Lord, 2008; as cited in: Brody, Bugusu, Han, Koelsch Sand and Mchugh, 2008). Traditional food packaging forms a passive barrier designed to delay the adverse effects of the environment on a food product (Brody et al., 2008). Innovative intelligent packaging systems can create an enhanced product by using non-traditional packaging functions to provide safer, nutritious or more attractive food products, while being environmentally friendly. In addition, intelligent packaging technologies can be further optimized by incorporating nanotechnologies to actively or intelligently improve or enhance packaging functions (O'Callaghan and Kerry, 2016; Sokolović, 2018). The food industry is also largely shifting from passive packaging to innovative packaging to cope with global trends, technological advances and consumer preferences (Mlalila, Kadam, Swai and Hilonga, 2016; Dainelli, Gontard, Spyropoulos, Zondervan-Van Den Beuken and Tobback, 2008). Adoption of suitable packaging technologies by the food industry can be useful for prolonging durability, improving quality, safety and providing product information (Biji, Ravishankar, Mohan and Srinivasa Gopal, 2015). Moreover, innovation systems can improve the quality of consumer life and product quality, consequently, reducing the number of complaints from sellers and consumers (Dobrucka and Cierpiszewski, 2014).

Traditional perception of packaging classifies the main functions of packaging into four basic categories: protection, communication, convenience and containment (Paine, 1991; Robertson, 1993; as cited in: Yam, Takhistov and Miltz, 2005; Gordon, 2012). Nevertheless, these functions are not totally exclusive - for example, the communication function of the package can also help to enhance food protection and convenience. The package is to (Yam et al., 2005; Yam and Sun Lee, 2012):

- Protect the product against deteriorative effects of the external environment,

- Communicate with the consumer as a marketing tool,

- Provide the consumer with greater ease of use and time-saving convenience,

- Contain products of various sizes and shapes.

Innovative packaging is the result of creative, unconventional thinking outside the usual framework of thought (Yam et al., 2005). The result of an innovative approach to packaging is the creation of packaging with interactive features. Actually, two groups of such packaging systems are distinguished: intelligent and active packaging. 
They are to improve packaging functions to meet current consumer demands. Active packaging represents a shift in the perception of functions, namely, the protection function of packaging has been shifted from passive to active. In the traditional perception, the protection function of a package meant a passive barrier between the product and its environment. Regarding active packaging, the aim of the protective function is to actively protect the product (Yam et al., 2005). Active packaging enables to actively change the condition of the package to extend shelf life or improve food safety while maintaining the quality of the food (Kačeňák, 2011). Following the definition of active packaging materials, they can be grouped according to the way in which they affect the characteristics of the product as follows: absorbers - active packaging systems based on absorption, and emitters - active packaging systems based on the release of substances (Sosnovcová, 2008; Robertson, 2012).

Intelligent packaging is a packaging system that is capable of carrying out intelligent functions (such as detecting, sensing, recording, tracing, communicating, and applying scientific logic) to facilitate decision-making to extend shelf life, enhance safety, improve quality, provide information, and warn about possible problems (Yam et al., 2005). According to Kačeňák (2011), the intelligent packaging is the term for systems that monitor conditions around the product and thus provide information about the quality of food during transport and storage. The following indicators are distinguished: time-temperature indicators, indicators of oxygen and carbon dioxide, the temperature indicators, pathogen indicators and breakage indicators (Sosnovcová, 2008). The importance of active and intelligent packaging means mainly significant expansion of two packaging functions: protective function - especially in active packaging shift from passive to the active protection, and information function - especially understood as providing information about monitoring of the packing conditions by intelligent packaging (Loučanová, Kalamárová and Parobek, 2017a; Šajtroch and Nosál'ová, 2018).

Packaging is one of the most important product attributes which influences the shopping preferences of consumers. Consumer attitudes to active and intelligent packaging vary from country to country. According to Brennan and Crandison (2011) active packaging materials have been generally accepted in the US, Australia, Japan, but much less in European countries. But some intelligent packaging materials are more widely used in European countries. The reasons of these different attitudes are not clear. These may be partly due to cultural differences and a lack of understanding for the functions and benefits. The consumers need to be better informed about the purpose and use of active and intelligent packaging systems to boost their wide-scale use and acceptance. According to the publication Europe Active and Intelligent Packaging Market - Forecasts (2016), the Europe as an active and intelligent packaging market is witnessing a remarkable growth and it is estimated to grow rapidly by the end of 2020. This market growth is driven by increasing demand for these packaging products because of changing lifestyles and demand from manufacturers for longer shelf life.

As mentioned by Prasad and Kochhar (2014), intelligent and active packaging offers considerable potential as a marketing tool. However, the development and 
implementation of this type of packaging will depend on the acceptance and cost effectiveness for the industry and consumers.

Therefore, awareness of consumer attitudes towards the new generation of packaging is a valuable source of information for producers when developing marketing strategies linked to designing and placement on the market of new goods (Barska and Wyrwa, 2016).

Starting from the above the aim of the paper is to identify preferential packaging functions and preferences of customers belonging to the Millennial Generation in Slovakia, according to the product packed in either intelligent or active packaging, which reflects the packaging function.

\section{Methodology}

The questionnaire survey was used for identification of consumer preferences for intelligent and active packaging in Slovakia. We examined preferential packaging functions and preferences of customers according to the product packed in specific intelligent or active packaging which reflects the packaging function. As examples we used specific food products in researched types of packaging, which allows for deeper manifestation and understanding of innovative packaging functions by the respondents.

According to our previous research (Loučanová, Parobek and Kalamárová, 2016; 2017a; Loučanová, Nosál'ová, Parobek and Dopico, 2018) intelligent and active packaging has different impact on customers in different age categories. We have confirmed the interest of the younger generation (15-26 years old), for whom this kind of packaging is most attractive (Loučanová et al., 2018). These findings are consistent with O'Callaghan and Kerry (2016), who established that older people and women are more concerned, less-positive and more likely to perceive fewer benefits associated with smart packaging technologies.

Due to the above, we focus on the respondents in the above age group with the highest potential to be attracted by concrete products in active or intelligent packaging. The sample for this research was respondents referred to as the Millennal Generation. According to the Merriam-Webster Dictionary (2018), the term Millennial Generation describes the generation of people born between the early 80s and 90s.

The questionnaire was proposed and formulated by the members of project as an output of COST Action FP1405 "Active and Intelligent Fibre-Based Packaging - Innovation and Market Introduction (ACTINPAK)". Pilot testing of the questionnaire, its correctness and comprehensibility was carried out among the members of this international project. Subsequently the language corrections according to comprehensibility in Slovak language were made.

The validity of the survey was determined by the methodology for respondents' sample calculation (Richterová, Labská, Vokounová, Klepochová and Žák, 1999): 


$$
\mathrm{n}=\frac{\mathrm{Z}_{1-\alpha / 2}^{2} * \mathrm{~S}^{2}}{\mathrm{H}^{2}}
$$

where:

$\mathrm{Z}_{1-\alpha}^{2}-$ required confidence level,

$\mathrm{H}-$ margin of error,

s - standard deviation.

The sample of respondents was determined at a confidence level of $95 \%$, with a margin of error of $+/-7 \%$ and standard deviation of 0.5 , which at the given data represents the value of 196 respondents to be the representative sample.

The survey was conducted online using Google form in the period from January to March 2018. During this time, responses from 200 respondents belonging to the millennials category were received in total. The average age of respondents was 24 years of age. In terms of gender, women and men were represented equally. With regard to the economic situation of the respondents due to the age categories, they were mostly students and working students $(73 \%)$.

The questionnaire was structured and consisted of closed question types. The response options were expressed with the help of the Likert scale in the interval of consent 1-7. The weight of consent 1 means that the statement is not important or the respondent does not fully agree with the statement. The weight of consent 7 means that the statement is very important, or the respondent fully agrees with the statement. Using this scale, it is not only possible to identify the attitude towards the packaging function, but also its importance for the respondent. The results of the questionnaire were processed in a database and quantitatively evaluated.

\section{Respondents' attitude to packaging functions}

As a result of global developments and progress, significant changes are evident in the approach to packaging materials, techniques as well as consumers' attitude towards the product packaging and its preferred functions. The essential functions are protection, handling, information and publicity, environmental and economic functions. Currently, different authors deal with several ways of packaging functions classification, the main functions of packaging are classified into four basic categories: protection, communication, convenience and containment. The importance of active and intelligent packaging means mainly significant expansion of two packaging functions: protective and information functions.

According to the survey results, the respondents name as the most important packaging function - the protection function. It is considered to be the primary function of the packaging since the respondents attributed it to the interval of importance 5.32 . Actually, $24.1 \%$ of respondents have given the interval of importance 6 to the protection function and together $53.4 \%$ of respondents consider protection function as very important or the most important (Fig. 1). For respondents, the most important feature of protection function of the packaging was to protect against liquids, vapours and gases, which scored 5.6 out of 7 and $33.3 \%$ of the 
respondents rated it the most important weight 7 . The features such as antibacterial properties, ensuring hygiene, and taste preservation have gained weight of importance above 5, so we can assume that these properties will be appreciated by consumers even for specific packaging.

As significant are perceived also economical (5.08) and ecological function (4.89). In terms of economic function, consumers demand economic packaging reasonable use of resources for packaging and good value without enormous price increases. Consumers demand products that fit into their lifestyles and the packaging industry has to respond to this. Since the consumers increasingly tend to sustainable living, also the importance of the ecological function is still increasing. Also according to our previous findings (Loučanová et al., 2017a; Parobek, Loučanová, Kalamárová, Šupín and Repková Štofková, 2015; Kaputa, Paluš and Dzian, 2017), consumers in Slovakia perceive ecological function of packaging as attractive and they prefer a recyclable material from a non-recyclable material. These findings confirm research of Dopico (2017), who examined the perception of functions among millennials in Spain and the protection function was identified as one of the most important for them (with the level of importance 6.03).

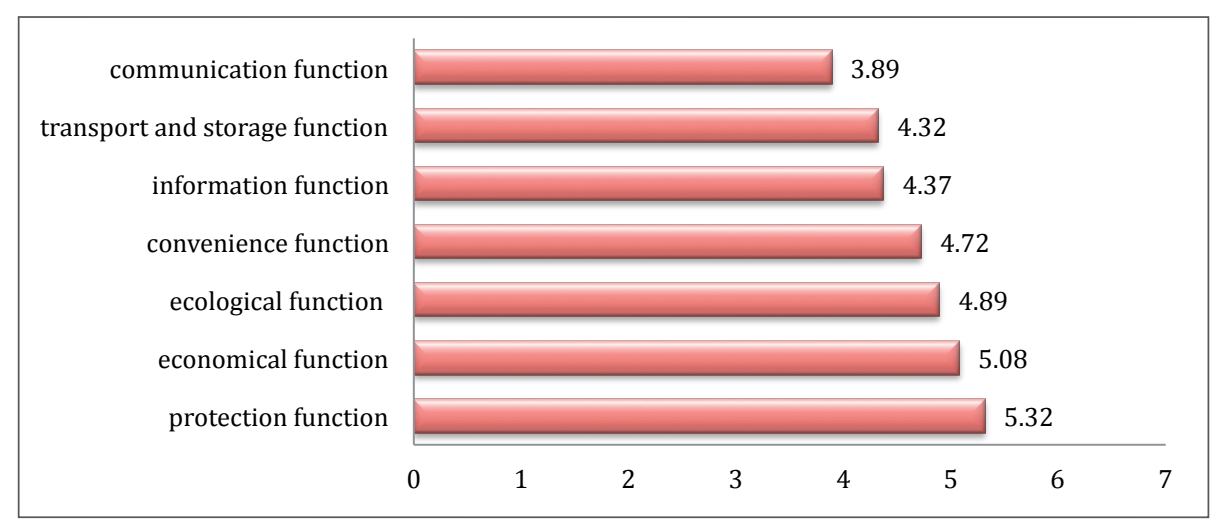

Fig. 1. The importance of packaging functions according to the respondents' attitudes.

Sources: own research.

Subsequently, we focused on identification of respondents' interest in innovative packaging. The individual features and functions of packaging were depicted by illustrations of specific products in innovative packaging. That allowed deeper understanding of the intelligent and active packaging. This was reflected, for example, in the fact that, despite low awareness of the terms intelligent and active (Loučanová et al., 2016, 2017a, 2018; O'Callaghan and Kerry, 2016; Dopico, 2017), the respondents recognized the individual types of food products in intelligent and active packaging and showed interest in them.

The identified strongest importance of protection function was reflected in interest in active packaging, which is characterized by the expansion of protection func- 
tion. The average interest in active packaging was identified at the level of 4.52 , what we consider as mild interest. Overall, the respondents have been interested mainly in such types of active packaging that prolong or ensure the freshness of the product (Fig. 2), what confirms the identified interest of consumers in food packages to prevent the microbial spoilage (Aday and Yener, 2015).

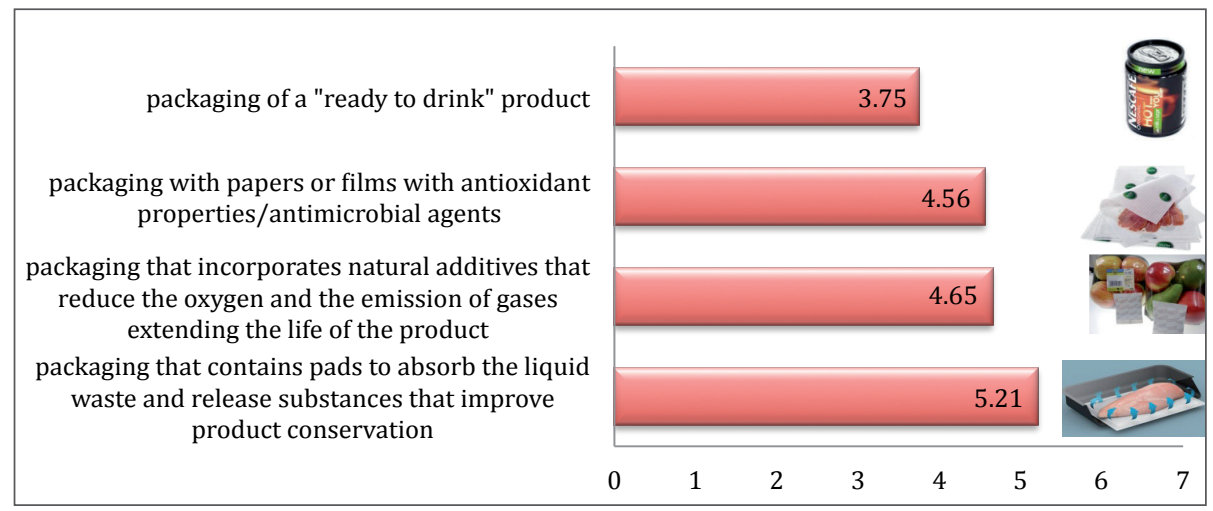

Fig. 2. The interest in active packaging functions according to the respondents attitudes. Sources: own research.

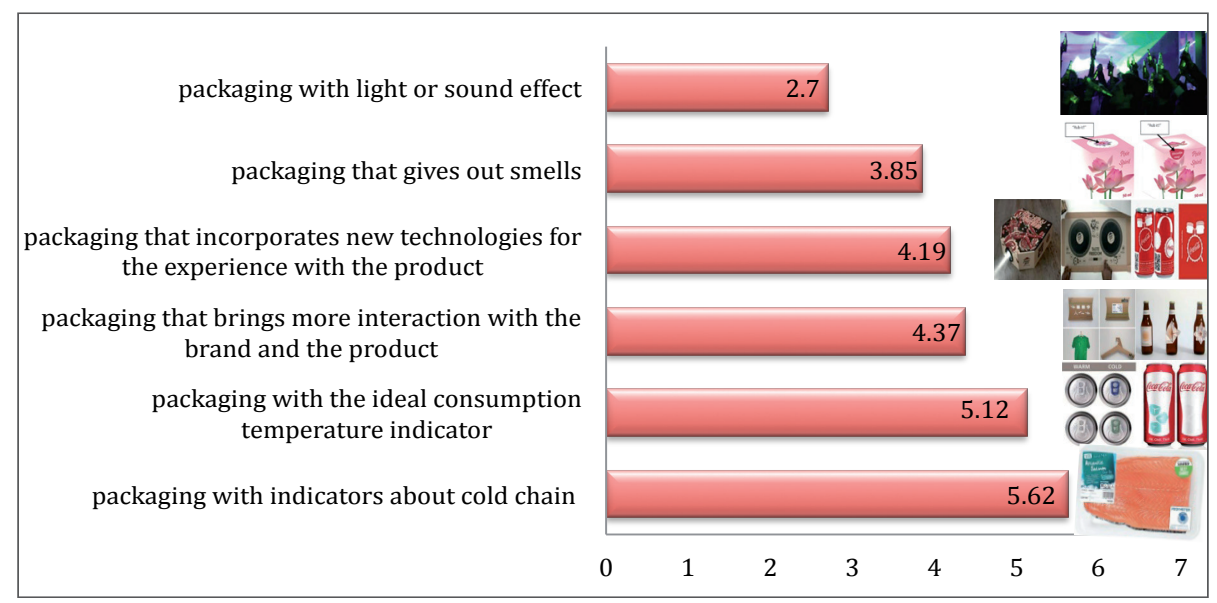

Fig. 3. The interest in intelligent packaging functions according to the respondents attitudes.

Sources: own research.

The average interest in intelligent packaging was identified at the level of 4.52, which is slightly lower than in terms of active packaging, the same preferences are evident regarding the Spanish millennials (Dopico, 2017). The most attractive packaging for respondents is the packaging that informs about the conditions inside the packaging or about the manipulation with the packaging and respondents 
consider it like a guarantee of quality (Fig. 3), confirming Aday and Yener (2015). Our findings also correspond to industry leaders' identification of freshness indicators as the most important innovation in the field over the next five years (Report The Future of Active and Intelligent Packaging in Food and Drinks, as cited in Harrington, 2010). The least interest was manifested in interactive packaging with light, sound or smell effects.

The actual attention and concern in active and intelligent packaging was reflected also in the willingness to pay more for products in these forms of packaging. A total of $80.1 \%$ of respondents were willing to pay more for products in intelligent or active packaging. The majority of them accept a maximum increase of up to $10 \%$ compared to the price of a product in a traditional packaging, that correspond to the findings of Dopico (2017), and Aday and Yener (2015).

The positive finding of the research is a fact, that respondents express the interest regarding the concept of intelligent and active packaging, even in cases where they have not met with specific products yet. The very term is attractive for them and it arouses curiosity and interest which can be used in the creation of marketing strategy for products in active or intelligent packaging.

\section{Conclusions}

The success of any innovation, which includes also intelligent and active packaging, definitely depends on customers understanding, awareness and recognition of the future benefit of the innovation. It should be noted that despite recognizing the occurrence of products in active and intelligent packaging on the Slovak market, the customer awareness of these innovative forms of packaging is still at a very low level (Loučanová et al., 2016, 2017b).

The identified importance of protection function of packaging for respondents was reflected in the interest in active packaging, which is characterized by expansion of protection function. Protection function is still perceived as the primary one and most importantly ensuring the freshness and shelf life of the products. Respondents' interest is slightly higher on active packaging as they extend the protection of the product and thus extend the life of the product, but also increase its safety. Taking into account the specific examples of products in specific intelligent or active packaging which reflects the packaging function, the respondents expressed interest manifested in concern when buying the product.

On the basis of the above, intelligent and active packaging has the potential to represent a competitive advantage for products to meet customers' needs and to increase their satisfaction. Definitely, innovation diffusing and management cannot exist without customer research because acceptation of innovation is ultimately an important factor of innovation success (Loučanová et al., 2017c, 2018) not only on the domestic, but also global market. 


\section{Acknowledgment}

This paper is an output of COST Action FP1405 "Active and Intelligent FibreBased Packaging - Innovation and Market Introduction (ACTINPAK)", the Grant project 1/0756/16 "Identification of consumers' segments according to their affinity for environmental marketing strategies of business entities in Slovakia" and the Grant project 1/0473/16 "Dynamics and Determinants of Wood-Based Products Market in the Slovak Republic". 


\section{References}

Aday, M.S., Yener, U. (2015). Assessing consumers' adoption of active and intelligent packaging. British Food Journal, vol. 117, pp. 157-177.

Barska, A., Wyrwa, J. (2016). Consumer perception of active and intelligent food packaging. Problems of Agricultural Economics, vol. 4(49), pp. 138-159.

Biji, K.B., Ravishankar, C.N., Mohan, C.O., Srinivasa Gopal, T.K. (2015). Smart packaging systems for food applications: a review. Journal of Food Science Technology, vol. 52, pp. 6125-6135.

Brennan, J.C., Crandison, A.S. (2011). Food processing handbook. Wiley: 2011.

Brody, A.L., Bugusu, B., Han, J.H., Koelsch Sand, C., Mchugh, T.H. (2008). Scientific status summary. Innovative food packaging solutions. Journal of Food Sciences, vol. 73, pp. 107-116.

Dainelli, D., Gontard, N., Spyropoulos, D., Zondervan-Van Den Beuken, E., Tobback, P. (2008). Active and intelligent food packaging: legal aspects and safety concerns. Trends Food Science Technology, vol 19, pp. 103-112.

Dobrucka, R., Cierpiszewski, R. (2014). Active and Intelligent Packaging Food - Research and Development - A Review. Polish Journal of Food and Nutrition Sciences, vol. 64, pp. 7-15.

Dopico, A. (2017). The consumer perceived value: Development of a measurement scale for package functions. Retrieved from: http://www.actinpak.eu/wp-content/uploads/2017/11/Ana-Dopico.pdf.

Europe Active and Intelligent Packaging Market - Forecasts, Trends and Shares (2016). Retrieved from: https://www.businesswire.com/news/home/20160229006006/en/EuropeActive-Intelligent-Packaging-Market-2015-2020.

Gordon, R. (2012). Food packaging: principles and pratise. CRS Press: 2012.

Harrington, R. (2010). Future trends for active and intelligent packaging. Retrieved from: http:// www.bakeryandsnacks.com/Article/2010/06/22/Future-trends-for-active-and-intelligentpackaging.

Jakubíková, D. (2005). Strategický marketing. Praha: Oeconomica.

Kačeňák, I. (2011). Trendy rozvoja potravinárskej obalovej techniky. Bratislava: Vydavatel'stvo EKONÓM.

Kaputa, V., Paluš, H., Dzian, M. (2017). End-users'views on selected green properties of paper products. More Wood, Better Management, Increasing Effectiveness: Starting Points and Perspective. Proceedings of Scientific Papers, pp. 204-211.

Kollár, V. (1999). Systém a špecifikácia produktovej politiky. Bratislava: Sprint.

Kotler, P., Trias De Bes, F. (2005). Inovativní marketing. 1. vyd. Praha: Grada Publishing.

Loučanová, E., Kalamárová, M., Parobek, J. (2017a). Innovative approach to product packaging. Innovations in forestry, wood processing and furniture manufacturing. Zagreb.

Loučanová, E., Kalamárová, M., Parobek, J. (2017b). The innovative approaches to packaging - comparison analysis of intelligent and active packaging perceptions in Slovakia. Studia Universitatis Vasile Goldiş Arad. Seria Ştiinţe Economice.

Loučanová, E., Nosál'ová, M., Parobek, J. (2017c). Inteligentné inovácie a ich riešenia ako nástroj konkurencieschopnosti. 1. vyd. Zvolen: Technická univerzita vo Zvolene.

Loučanová, E., Nosálová, M., Parobek, J., Dopico, A. (2018). The Kano model use to evaluate the perception of intelligent and active packaging of Slovak customers. Studia Universitatis Vasile Goldis Arad - Economics Series, vol. 28, pp. 35-44.

Loučanová, E., Parobek, J., Kalamárová, M. (2016). The perception of respondents of packaging innovations in Slovakia. Studia Universitatis Vasile Goldiş Arad. Seria Ştiinţe Economice, vol. 26, pp. 33-43. 
Merriam-Webster Dictionary (2018). Defnition of millennial. Retrieved from: https://www.merriam-webster.com/dictionary/millennial.

Mlalila, N., Kadam, D.M., Swai, H. Hilonga, A. (2016). Transformation of Food Packaging from Passive to Innovative via Nanotechnology: Concepts and Critiques. Journal Food Science Technology, vol. 53, pp. 3395-3407.

O’ Callaghan, K.A.M., Kerry, J.P. (2016). Consumer attitudes towards the application of smart packaging technologies to cheese products. Food Packaging and Shelf Life, vol. 9, pp. 1-9.

Parobek, J., Loučanová, E., Kalamárová, M., Šupín, M., Repková Štofková, K. (2015). Customer window quadrant as a tool for tracking customer satisfaction on the furniture market. Procedia - economics and finance, vol. 34, pp. 493-499.

Prasad, P., Kochhlar, A. (2014). Active Packaging in Food Industry: A Review. Journal of Environmental Science, Toxicology and Food Technology, vol. 8, pp. 01-07.

Richterová, K., Labská, H., Vokounová, D., Klepochová, D., Žák, Š. (1999). Kapitoly z marketingového výskumu. Bratislava: Ekonóm.

Robertson, G.L. (2012). Food Packagin and Shelf Life. A practical Guide. Boca Raton: CRC Press.

Sokolović, M. (2018). Tackling food waste: turning nemesis into a saviour. EUFIC.

Sosnovcová, J. (2008). Aktivní a inteligentní obalové systémy pro balení potravin. Vedecký výbor pro potraviny. Brno.

Šajtroch, J., Nosál'ová, M. (2018). Vnímanie funkcií inteligentných a aktívnych obalov. ŠVOČ 59: $59^{\text {th }}$ international student's scientific conference, pp. 320-336.

Yam, K.L., Sun Lee, D. (2012). Emerging Food Packaging Technologies: Principles and practice. Cambridge: Woodhead Publishing.

Yam, K.L., Takhistov, P.T., Miltz, J. (2005). Intelligent Packaging: Concepts and Applications. Journal of Food Science, vol. 70, no. 1. 


\title{
POSTRZEGANIE FUNKCJI OPAKOWAŃ I ZAINTERESOWANIE INTELIGENTNYMI I AKTYWNYMI OPAKOWANIAMI
}

\begin{abstract}
Abstrakt
Znaczenie funkcji opakowań wciąż rośnie, a w konsekwencji podejście do opakowań jest bardziej innowacyjne i kreatywne, co skutkuje tworzeniem opakowań o innowacyjnych cechach, takich jak opakowania aktywne i inteligentne. Niniejszy dokument bada funkcje preferencyjne opakowań i preferencje klientów w odniesieniu do inteligentnych i aktywnych opakowań. Badanie ankietowe przeprowadzono z udziałem 200 respondentów, których można określić jako milenialsów (osoby urodzone w latach 1980-2000). Ta grupa wiekowa została wybrana ze względu na poprzednie wyniki badań, co potwierdziło, że inteligentne $i$ aktywne opakowania sa najbardziej atrakcyjne dla respondentów $w$ tym wieku. Funkcja ochrony jest nadal postrzegana jako podstawowa i, co najważniejsze, zapewniajaca świeżość $i$ trwałość produktów. Zainteresowanie respondentów jest nieco wyższe w przypadku opakowań aktywnych, ponieważ podnoszq one poziom ochrony produktu, a przez to przedtużaja żywotność produktu, ale również zwiększaja jego bezpieczeństwo. Analiza zezwala na bardziej szczegółowe sugestie dotyczace marketingu aktywnych i inteligentnych opakowań w odniesieniu do wymogów klientów.
\end{abstract}

Słowa kluczowe: innowacyjne funkcje opakowań, aktywne, inteligentne, preferencje milenialsów.

Accepted for print: 18.12.2018.

Unless stated otherwise all the materials on the website are available under the Creative Commons Attribution 4.0 International license.

Some rights reserved to the Institute of Agricultural and Food Economics - National Research Institute.

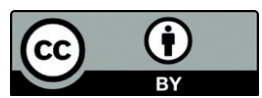

